\title{
REJECTED SYRIANS: VIOLATIONS OF THE PRINCIPLE OF “NON-REFOULEMENT” IN TURKEY, JORDAN AND LEBANON
}

\author{
Vasja BADALIČ
}

COBISS 1.01

\section{ABSTRACT \\ Rejected Syrians: Violations of the Principle of "Non-Refoulement" in Turkey, Jordan and Lebanon}

The article analyses the practices used by Turkey, Jordan and Lebanon to prevent Syrians from exercising their right to seek and enjoy asylum. The article consists of two sections. The first section examines how all three host countries violated the principle of non-refoulement by employing a range of unlawful practices (e.g. border closures and "pushbacks", arbitrary detentions and deportations etc.). The second section examines how Lebanon resorted to practices that created circumstances for constructive refoulement of Syrian asylum seekers and refugees (e.g. shutting down the authority responsible for processing asylum claims, stripping Syrian refugees of their protected status etc.).

KEY WORDS: Syrian refugees, Turkey, Jordan, Lebanon, principle of non-refoulement, constructive refoulement

\section{IZVLEČEK}

\section{Zavrnjeni Sirci: Kršitve načela nevračanja v Turčiji, Libanonu in Jordaniji}

Članek analizira prakse, ki so jih Turčija, Jordanija in Libanon uporabili z namenom, da sirskim državljanom preprečijo uveljavljanje pravice do iskanja in uživanja pribežališča pred preganjanjem. Članek je sestavljen iz dveh delov. Prvi del analizira, kako so vse tri države gostiteljice $z$ uporabo nezakonitih praks kršile načelo nevračanja (npr. zapiranje meja in preprečevanje prehoda, samovoljno zapiranje in deportiranje itd.). Drugi del članka analizira, kako je Libanon uporabil prakse, ki so ustvarile pogoje za posredno prisilno vračanje sirskih iskalcev azila in beguncev (npr. zaprtje edine institucije, pristojne za obravnavanje prošenj za azil, odvzem statusa nekaterim sirskim beguncem itd.). KLJUČNE BESEDE: sirski begunci, Turčija, Jordanija, Libanon, načelo nevračanja, posredno prisilno vračanje

PhD in Philosophy; Researcher; Institute of Criminology at the Faculty of Law in Ljubljana, Poljanski nasip 2, SI-1000 Ljubljana; vasja.badalic@pf.uni-lj.si — The author acknowledges that this project received funding from European Union's Horizon 2020 research and innovation programme under the Marie Skłodowska-Curie grant agreement no. 734855. The author also acknowledges the project was financially supported by the Slovenian Research Agency ("Crimmigration between human rights and surveillance", ID: J5-7121 B). 


\section{INTRODUCTION}

Since the start of the Syrian conflict in 2011, the vast majority of Syrian refugees have found shelter in Syria's neighbouring countries - Turkey, Lebanon, and Jordan (UNHCR 2017a). The three host countries adopted two approaches to address the challenges represented by the massive number of Syrians seeking safe refuge. The first approach, used in the first two years of the conflict, was to maintain an open door policy for Syrian asylum seekers and grant them limited protected status and access to the most basic services (Akram et al. 2014; Al 2014a; NRC 2014). The second approach, gradually implemented when the number of Syrians seeking shelter reached unsustainable levels, shifted to a closed door policy. In October 2014, for example, the Lebanese authorities approved a new policy on Syrian refugees with the objective of reducing the number of Syrians in Lebanon by limiting cross-border movements from Syria and by "encouraging" Syrian refugees in Lebanon to return to their homeland (Janmyr 2016: 61-62). Although Turkey and Jordan did not announce the end of their open door policy, it was evident, based on the measures they adopted to prevent Syrians from crossing the borders, that both countries took a similar path as Lebanon.

While it is true that all three host countries should be commended for providing aid to such a large number of Syrian refugees, it is also important to examine how these countries tried to control the influx of Syrians by relying on practices in direct contravention of international law. This article focuses on the implementation of the closed door policy in order to examine how Turkey, Jordan and Lebanon tried to stop, or at least limit, the continuing mass influx of Syrian asylum seekers. The central part of the article consists of two sections. The first section examines how all three host countries systemically violated the principle of non-refoulement by employing a range of unlawful practices that aimed at stopping Syrian asylum seekers in their attempts to cross the borders and gain access to the authorities responsible for making protection status determinations. Those unlawful practices included border closures and push-backs of Syrian asylum seekers trying to cross the borders, the introduction of discriminatory criteria for determining which groups of Syrian asylum seekers were not allowed to cross the borders, as well as arbitrary detentions and deportations of Syrian asylum seekers. The second section of the article examines how one of the host countries - Lebanon - resorted to practices that created circumstances for constructive refoulement of Syrian asylum seekers and refugees. Those practices included shutting down the sole authority responsible for processing asylum claims, de-registering Syrians with protected status, and preventing Syrian refugees from obtaining/retaining residency permits.

1 The European Union (EU) made a similar, albeit much more rapid, shift from an open door to a closed door policy. In late 2015, the so-called humanitarian corridor temporarily allowed large numbers of refugees, including Syrian refugees, to reach the EU through the Western Balkans (Kogovšek Šalamon 2017). In early 2016, however, the corridor was closed and the EU returned to its closed door policy (Oxfam 2017). 


\section{VIOLATIONS OF THE PRINCIPLE OF “NON-REFOULEMENT”}

The principle of non-refoulement prohibits the return, in any manner whatsoever, of individuals to another territory, or to the frontiers of another territory, where there are substantial grounds for believing that they would be subjected to torture or degrading treatment, or where they would be subjected to other serious deprivations of human rights (UN General Assembly 1951; Feller 2006: 523). Considered part of international customary law and recognized, as some authors argued, as a jus cogens norm, the norm prohibiting refoulement binds all states, regardless of whether or not they are a party to the 1951 Refugee Convention, to refrain from expelling people to territories where their lives and freedoms may be threatened (Allain 2001: 538-542; Farmer 2008: 23-28). Although Jordan and Lebanon are not signatories to the 1951 Refugee Convention, while Turkey maintains a "geographical limitation" to the Convention in order to avoid applying it to non-European refugees (Akram et al. 2014: 34, 59, 101), all three countries are bound to respect the obligation not to return individuals, either formally recognized refugees or non-recognized refugees, to territories where their lives may be in danger. Hence, all three countries have to observe the principle of non-refoulement both at their borders and within their territories (UNHCR 1977).

Over the past decades, human rights law scholars have developed the idea that there should be no exceptions to the prohibition of refoulement. That trend, which treated the right of non-refoulement as a non-derogable right, embraced the stance that people should never be, under any circumstances, deported to a territory where they may face the risk of persecution (Lauterpacht, Bethlehem 2001: 131-132; UNHCR 1980; UNHCR, OAU 1980). UNHCR, for example, supported the position that even in cases of large-scale influx "the fundamental principle of non-refoulement - including non-rejection at the frontier - must be scrupulously observed" (UNHCR 1981). There is, however, still a strong recognition among states that in some circumstances it is possible to lawfully expel refugees and asylum seekers to territories where their lives and freedoms would be in danger. That position primarily relies on the 1951 Refugee Convention, which states in Article 33(2) that it is permissible to lawfully expel individuals who represent a danger to the national security of the host country, and individuals who are recognized, after being convicted of a serious crime by a court of law, as a danger to the community of the host country (UN General Assembly 1951).

The application of exceptions to the principle of non-refoulement is therefore permissible but must be subjected to two limitations. Firstly, exceptions to non-refoulement are permissible only when individuals pose a real threat to national security or a danger to the community of the country of refuge. Threats to national security may include espionage, attacks on military installations and terrorist activities in the host country (Grahl Madsen 1997: 235-236), while dangers to the community may include serious crimes such as murder, rape, or arson (Lauterpacht, Bethlehem 2001: 139). Secondly, exceptions can be applied only in compliance with due process 
of law. When, for example, host countries want to return individuals due to concerns about public safety, they are allowed to do so only if those individuals had been convicted of a serious criminal offence by a court of law operating in compliance with minimum international standards (ibid.: 138-140). All such cases of refoulement require individual assessment and must be supported by evidence (ibid.).

This section aims at examining whether Turkey, Jordan and Lebanon applied these exceptions, and respected the limitations that restrict the scope of the exceptions, when they carried out mass rejections of Syrian asylum seekers. The examination will focus on three practices used by Turkey, Jordan and Lebanon to carry out rejections of Syrians in order to determine whether the three countries observed the limitations restricting the exceptions to non-refoulement. The three practices are as follows.

\section{Border Closures and Push-Backs}

The first practice, which targeted Syrian asylum seekers who did not yet enter the three host countries, was to sporadically close borders, especially during escalations of violence in Syria, and carry out "push-backs" of people trying to flee Syria. ${ }^{2}$

In Turkey, security forces have sporadically used border closures and push-backs against Syrians since at least 2012 (Dinçer et al. 2013: 5; Koca 2015: 216-217; HRW 2013b). When carrying out push-backs, Turkish border guards resorted to unlawful use of force that included shooting at and beating Syrians trying to cross the border. In a few cases, the use of abusive force resulted in Syrians being killed or injured (Al 2014a: 9-10; HRW 2015; Rifai 2015; HRW 2016a). In addition, the Turkish authorities regularly closed official border crossings, particularly in the south-east of the country where they wanted to prevent access for Syrians fleeing from areas with a predominantly Kurdish population (Al 2014: 9-10). When the fighting across Syria intensified and the number of Syrian asylum seekers continued to increase, the Turkish authorities opted to close the entire border. From early 2015 to mid-2016, the Turkish-Syrian border remained virtually closed, which led to an estimated 165,000 Syrian asylum seekers being stranded on the Syrian side of the border (DRC 2016: 4).

A similar tactic was adopted by Jordan. From mid-2014 to mid-2016, the Jordanian authorities closed the border to temporarily prevent the entry of about 70,000 Syrian asylum seekers. The Jordanian security forces trapped the Syrians in a desert area just a few hundred metres south of the Jordanian-Syrian border (HRW 2016b).

In Lebanon, they permanently closed the border to almost all Syrian asylum seekers in early 2015. In that period of time, the Lebanese government introduced new regulations that allowed the entry into Lebanon only of Syrians with valid travel documents who fit into one of the seven approved entry categories (e.g. tourism

2 According to the European Center for Constitutional and Human Rights (ECCHR 2018), pushbacks are state measures that aim at forcing refugees and migrants back over a border - usually immediately after they cross it - without providing them the opportunity to apply for asylum. 
and business, education, transiting to a third country, medical treatment, displacement in the country of origin, etc.) (Janmyr 2016: 66-67). After the introduction of the new entry regime, the Lebanese government announced strict rules for determining which groups of displaced Syrians would be admitted into the country. According to the new rules, only the following groups of displaced Syrians were allowed to enter Lebanon: unaccompanied and/or separated Syrian children with a parent already registered as a refugee in Lebanon; Syrians with disabilities and a relative already registered in Lebanon; Syrians with urgent medical needs for whom treatment in Syria was unavailable, and Syrians who had already arranged a resettlement to a third country (ICL 2015). By implementing these entry requirements, I contend, the Lebanese government effectively closed the border to the vast majority of Syrian asylum seekers.

By relying on practices that physically prevented asylum seekers from crossing the borders and reaching the authorities responsible for status determination procedures, all three host countries systemically violated the principle of non-refoulement. Mass rejections of potential asylum seekers at the frontiers are a clear violation of the norm prohibiting refoulement (Lauterpacht, Bethlehem 2001: 118-119). Even if we take into account the exceptions to the principle of non-refoulement, we see that none of the three countries was able to justify the mass rejections by presenting them as lawful exceptions. First, none of the host countries provided compelling evidence indicating that the returns were carried out because those who were rejected represented a real threat to the national security and/or public safety of the host countries. Second, none of the host countries examined the facts of each individual case of those who were rejected. The host countries were unable to claim that the rejected individuals represented a threat to public safety because they did not check at the border crossings whether those individuals had been convicted of any crime by a court of law operating in compliance with minimum international standards.

\section{Discriminatory Criteria}

The second practice targeted Syrians, and non-Syrians living in Syria, who had not yet managed to enter the host countries. This practice relied on the use of selective criteria for determining which groups of asylum seekers were not allowed to cross from Syria into the host countries. In parallel with sporadic border closures and push-backs, the governments of all three host countries implemented discriminatory policies that prevented specific categories of Syrians and non-Syrians from seeking protected status.

The first category consisted of people of specific national origins - i.e. Palestinian refugees and Iraqi refugees living in Syria. In Jordan, for example, the authorities started to deny entry to all Palestinians from Syria in April 2012 (ARDD 2015; UNHCR 2017b: 2). Jordanian government officials justified their decision by claiming that a 
large number of Palestinians in Jordan would alter the demographic balance of the country and, consequently, create a security threat (HRW 2014: 12-13; Al 2013: 10). In addition, the Jordanian authorities also denied entry to Iraqi refugees who had previously found shelter in Syria. That decision was justified with the argument that Iraqis had to return to their country of origin, which was deemed safe by the Jordanian government (AI 2013: 10).

In Lebanon, the local authorities closed the border to the vast majority of Palestinians from Syria. Although Lebanese officials insisted that the open door policy for Syrian refugees, including Palestinians, remained in place, the strict entry requirements gradually introduced for Palestinians made it almost impossible for most of them to enter Lebanon (UNHCR 2016: 12-13).

In mid-2013, the Lebanese authorities made the first changes in the entry requirements for Palestinians from Syria. Entry into Lebanon was allowed only to Palestinians who had one of the following: a visa that had to be obtained through an application made by a guarantor in Lebanon; a visa and a ticket to a third country in order to prove they were only transiting through Lebanon; evidence indicating they had a scheduled medical or embassy appointment in Lebanon; or evidence indicating they had family members already legally residing in Lebanon (AI 2014b: 11). In mid-2014, the Lebanese authorities introduced new changes in the regulations to further restrict the entry of Palestinians from Syria. The new rules stipulated that Palestinian asylum seekers would be admitted into Lebanon only if they met one of the following requirements: an entry permit approved by the General Directorate of General Security, the Lebanese intelligence agency; a one-year or three-year residence permit; an exit and return permit; or a ticket and visa to a third country (Al 2014b: 14; UNHCR 2017b, 1-2). By creating such strict requirements for the entry of Palestinians, the Lebanese authorities virtually closed the border to the vast majority of Palestinians seeking asylum.

The second category of Syrians who were not allowed to enter Jordan consisted of Syrian asylum seekers of a specific gender and marital status. In 2013, the Jordanian authorities decided to close the border to single men from Syria (HRW 2013a). Although Jordanian officials did not explain the reason behind their decision, it seems they believed that single military-aged men represented a potential security threat for the country.

The third category consisted of Syrians who lacked proper travel documentation. During the Syrian conflict, all three host countries decided that Syrians without valid documentation would not be allowed to cross the borders. In 2013, for example, the Jordanian security forces routinely prevented undocumented Syrians, most of them asylum seekers, from entering Jordan (HRW 2013a). In 2014, the Turkish authorities started denying entry to Syrians without passports at official border crossings. The temporary measure impacted a large number of Syrians seeking protection, as most of them did not have valid travel documents (Al 2014a: 9). At the beginning of 2015, the Turkish government made that measure permanent by 
announcing new regulations that required all Syrian asylum seekers entering Turkey to present a valid travel document (HRW 2015). Lebanon made a similar decision at that time. In early 2015, when the Lebanese government introduced a new visa regime for Syrians, only Syrian citizens with valid travel documents and visas were allowed to enter Lebanon (Janmyr 2016: 66-67).

The fourth category, a category of Syrians who were prohibited from entering Lebanon in 2014, consisted of Syrian asylum seekers fleeing from specific locations within their war-torn country. On the one hand, the Lebanese authorities claimed that some areas within Syria remained safe, and, consequently, prohibited individuals fleeing from those areas from entering Lebanon (HRF 2014). On the other hand, the Lebanese authorities also decided to allow only Syrian asylum seekers living in areas near the Syrian-Lebanese border to enter Lebanon, and, as a result, prevented the entry of individuals who fled from Syrian villages and cities located far from the Syrian-Lebanese border (ibid.).

The result of all of the abovementioned entry requirements is that many Syrians, and non-Syrians living in Syria, were not able to reach safe places and seek protection in Turkey, Jordan, and Lebanon. By introducing discriminatory restrictions based on nationality, gender, marital status, possession of travel documents and geographical location, the authorities in Turkey, Jordan and Lebanon again breached the principle of non-refoulement. The three host countries were again unable to justify the mass rejections at the borders by presenting them as lawful exceptions to the norm prohibiting refoulement. First, all three countries failed to provide evidence indicating that the returns were necessary in order to protect the national security and/ or public safety of the host countries. The Jordanian authorities merely speculated that large numbers of Palestinian refugees may pose a threat to national security in the future. The rejections of Palestinians were therefore unlawful because they were grounded on the assumption that a threat may materialize in the future and not on actual criminal acts committed by Palestinian refugees (e.g. terrorist attacks, espionage, etc.). Second, the three host countries failed to provide individual assessments of those who were returned. The rejections targeted specific groups of Syrian asylum seekers without examining the facts of each individual case.

\section{Detentions and Deportations}

The third practice, used sporadically by Turkey and Jordan, was to detain and deport Syrian asylum seekers and refugees who were already in the countries.

In Turkey, in September 2015 the local security forces started detaining and deporting registered Syrian refugees and asylum seekers who attempted to cross irregularly to Greece (Al 2015: 1). The detentions were arbitrary: the Turkish authorities did not inform the detainees why they were being deprived of their liberty, although they later claimed, without providing references to the law, that the detainees may 
be held in detention on grounds of security or because they were involved in criminal acts (AI 2015: 3-6). While holding refugees in detention, usually for a period of up to two months, the security forces refused to allow them to contact their family members and lawyers (ibid.). In early 2016, after sealing the border with Syria, the Turkish security forces were detaining and deporting Syrian refugees found without their registration documents and asylum seekers who were attempting to register in the border province of Hatay (AI 2016). The detentions were arbitrary: the Turkish authorities did not inform the detainees, at the time of their arrests, of the reasons for the arrests and of any charges against them, and they did not bring the detainees before a judge or any other official authorized to exercise judicial power in accordance with procedures established by law (ibid.). In that period, the Turkish authorities carried out operations on a nearly daily basis in which they arrested and deported groups of up to 100 Syrian citizens seeking protection (ibid.). In 2018, Turkey detained and deported Syrians who tried to flee Idlib province in north-western Syria (Carrié, Al Omar 2018).

In Jordan, the security forces carried out detentions and deportations of asylum seekers who were prohibited from entering Jordan - i.e. Palestinian refugees from Syria. After the Jordanian government stopped allowing Palestinians from Syria to cross into Jordan, the Jordanian police and intelligence agency started detaining and deporting Palestinians who entered the country irregularly (HRW 2014: 18-22). It was unclear whether the security forces carried out the detentions and deportations arbitrarily or on the basis of a law criminalizing irregular migration. As a result of the non-admission policy, all Palestinian asylum seekers, including women and children, who entered Jordan irregularly were deemed to have committed an immigration crime and were, consequently, subjected to penalties provided by the law. Article 31 of the Law on Residence and Foreigners' Affairs (1973) stipulates that any person who enters Jordan without valid travel documents and visas through unofficial border crossings shall be liable to a term of imprisonment of between one and six months, or to a fine of between 10 and 50 Jordanian Dinars, or both. In addition to fines and/ or imprisonment, the law also provides for the expulsion of foreigners who enter the country irregularly (GDP 2015: 7-10). The Palestinian asylum seekers arrested by the Jordanian security forces were usually held in detention for several days before being deported to areas in Syria under the control of Syrian anti-government forces (HRW 2014: 18-22; Akram et al. 2014: 64).

Like the first two practices examined above, the detentions and deportations carried out in Turkey and Jordan constituted a violation of the principle of non-refoulement. Both countries carried out the expulsions of refugees and asylum seekers without justifying them as exceptions to the norm prohibiting non-refoulement. First, neither Turkey nor Jordan provided compelling evidence to prove that those who were deported to their country of origin represented a threat to the national security and/or public safety of the host countries. Second, Turkey, which resorted to arbitrary detentions of asylum seekers and registered refugees, did not carry out 
the detentions and deportations in compliance with due process of law. The Turkish authorities did not prove that the rejected individuals represented a threat to public safety because none of the individuals concerned was convicted of any crime by a court of law.

\section{CREATING CIRCUMSTANCES FOR CONSTRUCTIVE “REFOULEMENT"}

The definition of the principle of non-refoulement broadly states that host countries shall not return refugees in any manner whatsoever to territories where their lives could be threatened (UN General Assembly 1951). Drawing on the broad wording employed to prohibit any act of removal, many authors argued that the concept of refoulement includes constructive refoulement, a form of refoulement that occurs when host countries deliberately deny refugees and asylum seekers their economic, social and cultural rights in order to leave them with no choice but to return to their unsafe country of origin (Edwards 2005: 322-323; Bhattacharjee 2013: 48-49; Ramsden, Marsh 2014: 275; Hathaway 2005: 464; Nessel 2015: 339-340). Constructive refoulement is, therefore, a form of refoulement that is not committed directly (e.g. through border closures and push-backs) but indirectly (e.g. through policies and practices that compromise the legal, material, and physical safety of asylum seekers and refugees) (Schneebaum 2010: 8-9). Some of the practices used by host countries to put pressure on asylum seekers and refugees in order to indirectly force them to return to their country of origin are as follows: denying asylum seekers access to fair and effective protection status determination procedures; limiting or completely denying refugees access to the formal labour market or opportunities for self-employment; denying asylum seekers and refugees access to basic services; and subjecting asylum seekers and refugees to human rights abuses (Kneebone 2006: 698-699; Bhattacharjee 2013: 48-49; Schneebaum 2010: 8-9).

While examining the practices used by Lebanon to create circumstances for constructive refoulement, we could focus on an array of measures that undermined the physical, material and legal safety of Syrians who found refuge within the country. This article, however, primarily focuses on the legal safety, or the lack thereof, of Syrian asylum seekers and refugees. The objective is to examine how various practices employed by the Lebanese authorities left many Syrians without legal status and thus put them under pressure to repatriate. The five practices that Lebanon used to create circumstances for constructive refoulement can be divided in two categories: first, practices that targeted Syrian asylum seekers to deny them access to protection status determination procedures in order to prevent them from exercising their right to seek asylum, and, second, practices that stripped Syrian refugees of protected status and prevented them from obtaining/retaining residence permits that would allow them to legally reside in the host country. 


\section{Denial of Access to Protection Status Determination Procedures}

The failure to provide fair and effective status determination procedures may result in constructive refoulement (Legomsky 2003: 73; Kneebone 2006: 698-699). If host countries fail to establish protection status determination procedures, they leave asylum seekers without a legal status and, consequently, without any rights and benefits (e.g. access to health services, employment, education etc.). When asylum seekers find themselves in such a precarious position, they may be indirectly forced to return to their country of origin.

The Lebanese authorities failed to provide fair and effective protection status determination procedures for Syrian asylum seekers by either limiting or completely preventing access to such procedures. First, following its decision to seal the border to the vast majority of Syrian asylum seekers, in May 2015 the Lebanese government ordered the UNHCR, the sole authority responsible for making protection status determinations in Lebanon, to suspend procedures for the registration of Syrians who were already in Lebanon and those who would arrive in the future (Janmyr 2016: 63-64). After the closure of the Lebanese-Syrian border, the vast majority of new asylum seekers from Syria were treated by the Lebanese authorities as irregular migrants who had no access to asylum. Although the Lebanese authorities justified their decision to prevent the UNHCR from registering new arrivals by promising that new status determination procedures would soon be established, no new procedures had been put in place by early 2017 (Janmyr 2016: 64; HRW 2017).

Second, even when Lebanon allowed UNHCR to process asylum claims, many Syrians remained without access to the UNHCR registration centres and thus unable to lodge asylum claims. The Lebanese security forces limited access to registration centres by regularly harassing and intimidating Syrian asylum seekers, in particular young men who entered the country irregularly (IRC 2016; HRW 2016c: 15-18). Many unregistered Syrian single men who were detained and subjected to ill-treatment while in detention decided to restrict their movements in order to avoid being detained again (IRC 2016). The constant experience of threat to their personal safety that came mainly from the Lebanese security forces and to a lesser extent from the local population forced many unregistered Syrian men to limit their movements to areas they knew (i.e. refugee camps or urban areas with a predominantly Syrian refugee population) (ibid.). Such "self-imposed" restrictions on the freedom of movement prevented many Syrian men from reaching UNHCR registration centres and seek protection (LHIF 2014: 11; IRC 2016). ${ }^{3}$

3 It was not possible to determine exactly how many Syrian men were unable to reach the UNHCR due to restrictions on the freedom of movement. The IRC (2016), which conducted interviews with 468 Syrian men in 2015, reported that 19 percent of them said they were unable to access UNHCR registration centres due to restrictions on the freedom of movement. 


\section{Denying Refugees Protected Status and Residency Permits}

The second category of practices that created conditions for constructive refoulement targeted registered Syrian refugees in order to deny them the right to enjoy asylum. These practices pursued two objectives: first, to strip Syrian refugees of their protected status, and, second, to prevent refugees from obtaining/retaining residence permits.

First, the Lebanese authorities introduced measures to strip Syrian refugees of their protected status. One of the measures was to de-register Syrian refugees who briefly returned to their country of origin (HRF 2014). Many Syrian refugees who found shelter in Lebanon temporarily returned to Syria in order to carry out activities they considered important (e.g. to help their family members flee from Syria, to sell the land they owned in Syria, to collect their salaries, etc.) (ibid.). Despite having legitimate reasons for briefly returning to their unsafe home country, those Syrians were stripped of their protected status and not allowed to re-enter Lebanon (ibid.). ${ }^{4}$ Another measure was to de-register Syrian refugees who entered Lebanon after the introduction of the border closure in early January 2015. In April 2015, the Lebanese government ordered UNHCR to de-register more than 1,400 Syrian refugees who had arrived in Lebanon, and had received protected status, after 5 January 2015 (ICL 2015). The Lebanese authorities refused to admit new refugees following the introduction of the border closure, and, therefore, they demanded that UNHCR remove the protected status of Syrians who had been granted limited protected status after the introduction of the border closure (ibid.).

Second, the Lebanese authorities introduced measures to prevent large numbers of registered Syrian refugees from obtaining/retaining residence permits. One measure, which was partially abandoned in early 2017, was to introduce fees that Syrian refugees registered with UNHCR had to pay in order to obtain the legal right to stay in Lebanon. The Lebanese government created a system in which registration with UNHCR did not automatically provide Syrian refugees with a right to stay in the country. If registered Syrian refugees wanted to legally reside in Lebanon, they had to apply for residence permits that were issued by the Lebanese authorities (LHIF 2014: 9). In addition to the right to stay in Lebanon, residence permits also granted

4 Article $1 \mathrm{~A}(2)$ of the 1951 Refugee Convention stipulates that the term refugee shall apply to a person that is outside the country of his nationality. Therefore, the refugee status of an individual can be terminated upon his re-establishment in his country of nationality because he no longer meets the criterion in Article 1A(2) (Grahl Madsen 1966: 370-371; Fitzpatrick, Bonoan 2003: 528). The Refugee Convention also states - in Article 1C(4) - that the Convention shall cease to apply to any person who "voluntarily re-established himself in the country which he left or outside which he remained owing to fear of persecution." However, automatic termination of protected status as a punishment for any return to the country of origin is inappropriate (Fitzpatrick, Bonoan 2003: 528-529). The revoking of protected status is inappropriate when a refugee makes only a brief visit to his country of origin (e.g. visit for family, political, or economic reasons) and his primary residence remains in the country of asylum (ibid.). This paper argues that the brief returns by Syrians to their country of origin were not a valid reason for terminating their protected status. 
other important rights and benefits such as access to healthcare at government facilities, the right to register births and marriages, and the right for students to take official exams at Lebanese schools (AI 2014b: 15).

The process for granting residence permits distinguished between Syrians who entered Lebanon through official border crossings and those who entered irregularly through unofficial border points (LHIF 2014: 9-10). Syrian refugees who entered Lebanon through official border crossings were initially granted, free of charge, residence permits for a period of six months. When the permits expired, Syrians could renew them, free of charge, for a new six-month period. After one year, all adult Syrian refugees (aged 15 years and above) again had to renew their residence permits, but at a cost of US \$200 per person/per year (NRC, IRC 2015: 13; LHIF 2014: 9). This fee proved to be an insurmountable obstacle for many destitute Syrian refugees. Many Syrians whose permits expired during their stay in Lebanon cited the prohibitive cost of renewal as the main reason that prevented them from renewing the permits (NRC 2014: 13; NRC, IRC 2015: 21). It was even worse for Syrian refugees who entered Lebanon through unofficial border crossings. Even if they somehow managed to register with UNHCR, it was very expensive for them to obtain residence permits from the Lebanese authorities. In order to legitimize their stay in Lebanon, they were expected to pay a fine for entering the country irregularly and fees for the period of time they lived illegitimately in Lebanon (LHIF 2014: 9). In some cases, the total cost for legitimizing a stay exceeded US $\$ 600$ per person (ibid.). As a result, many Syrian families who could not afford to pay such a large sum had no choice but to live illegitimately without residence permits. ${ }^{5}$

Another measure, which targeted Palestinian refugees from Syria, was to stop granting and renewing residence permits. After introducing the non-admission policy for Palestinian refugees from Syria, the Lebanese authorities started to refuse to renew residence permits for some of the Palestinian refugees who were already in Lebanon (AI 2014b: 15). In May 2014, for example, the Lebanese authorities called on Palestinian refugees from Syria to settle their status by applying for residence permits (ibid.). Some Palestinian refugees who went to the General Security office to legitimize their status were denied residence permits and given deportation orders with time periods ranging from 24 hours to one week (ibid.).

By demanding fees and fines from Syrian refugees, and by deciding to stop granting residence permits for Palestinian refugees from Syria, the Lebanese authorities ensured that many registered refugees remained without a residence permit, and, as a result, without the right to legally reside in Lebanon. By re-categorizing many Syrian refugees as irregular migrants (Oxfam 2015: 17), the Lebanese authorities undermined the legal safety of those refugees.

5 In 2015, the NRC and IRC (2015: 17-21) conducted interviews with 395 Syrian refugees in Lebanon. Out of the 395 refugees, 343 had a residence permit that expired during their stay in Lebanon. About half - 54 percent - of those 343 refugees said they were not able to renew their residence permits for a variety of reasons. The majority - 68 percent - of those unable to renew their residence permits said that the main reason was the cost of renewal. 


\section{CONCLUSION}

The right to seek and enjoy asylum is a fundamental human right originally enshrined in the Universal Declaration of Humans Rights and reaffirmed in numerous UN General Assembly Resolutions (UN General Assembly 1948; IMBR 2013). Although Turkey, Jordan and Lebanon opened their borders to millions of Syrian asylum seekers, the various anti-refugee practices introduced by all three countries indicate that many Syrians were prevented from exercising their right to seek and enjoy asylum. The first three practices examined above aimed at denying the right to seek and enjoy asylum by physically preventing Syrians from lodging asylum claims at UNHCR or any other authority responsible for protection status determination. The governments of all three host countries resorted to border closures and rejections of specific groups of Syrians in order to prevent new Syrian asylum seekers from crossing the borders and reaching the authorities responsible for protection status determination. In addition, two of the host countries - Turkey and Jordan - used arbitrary detentions and deportations to target Syrians who were already in their territories in order to prevent them from seeking and enjoying asylum.

The other practices used by Lebanon aimed at stripping registered Syrian refugees of their legal status in order to prevent them from enjoying asylum and thus to indirectly force them to return home. By shutting down the sole authority responsible for status determination procedures, by de-registering some Syrian refugees, and by not allowing Syrian refugees to obtain/retain residence permits, Lebanon compromised the legal safety of Syrians, stripped them of their rights and benefits, and thus put pressure on them to return to their unsafe country of origin. The pressure primarily emanated from the fact that Syrians who were not allowed to obtain/ retain protected status and residence permits were de facto re-categorized as irregular migrants, and, therefore, put at risk of being detained and deported. On the basis of a law criminalizing irregular migration in Lebanon, Syrians without protected status and residence permits were continually in danger of being imprisoned and deported. Article 323 of the Law Regulating the Entry and Exit of Foreigners in Lebanon and their Exit from the Country (1962) provides criminal charges and penalties - i.e. imprisonment of one to three months, payment of a fine, and expulsion from Lebanon - for individuals, including asylum seekers, convicted of entering and staying in Lebanon without valid travel documentation and visas.

\section{REFERENCES}

Al (Amnesty International) (2013). Growing Restrictions, though Conditions: The Plight of those Fleeing Syria to Jordan, https://www.amnestyusa.org/wp-content/uploads/2017/04/mde160032013en.pdf (24. 5. 2018). 
Al (Amnesty International) (2014a). Struggling to Survive: Refugees from Syria in Turkey, https://www.amnesty.org/en/documents/EUR44/017/2014/en/ (24. 5. 2008).

Al (Amnesty International) (2014b). Denied Refuge: Palestinians from Syria Seeking Safety in Lebanon, https://www.amnesty.org/en/documents/MDE18/002/2014/ en/ (24. 5. 2018).

Al (Amnesty International) (2015). Europe's Gatekeeper: Unlawful Detention and Deportation of Refugees from Turkey, https://www.amnesty.org/en/documents/ eur44/3022/2015/en/ (24. 5. 2018).

Al (Amnesty International) (2016). Turkey: Illegal Mass Returns of Syrian Refugees Expose Fatal Flaws in EU-Turkey Deal, https://www.amnesty.org/en/press-releases/2016/04/turkey-illegal-mass-returns-of-syrian-refugees-expose-fatal-flawsin-eu-turkey-deal/ (28. 5. 2018).

Akram, Susan M., Bidinger, Lang, Aaron, Hites, Danielle, Kuzmova, Yoana, Noureddine, Elena, Runnerstrom, Lys, Kistner, Timothy (2014). Protecting Syrian Refugees: Laws, Policies and Global Responsibility Sharing. Boston: International Human Rights Clinic at the University of Boston, http://www.bu.edu/law/files/2015/07/ FINALFullReport.pdf (25. 5. 2018).

Allain, Jean (2001). The Jus Cogens Nature of Non-Refoulement. International Journal of Refugee Law 13/4, 533-558.

ARDD (Arab Renaissance for Democracy and Development) (2015). Mapping the Legal Obstacles Palestinians Face in Jordan, https://ardd-jo.org/sites/default/files/ resource-files/mapping_the_legal_obstacles_palestinians_face_in_jordan_ en.pdf (15. 10. 2018).

Bhattacharjee, Saurabh (2013). Situating the Right to Work in International Human Rights Law: An Agenda for the Protection of Refugees and Asylum-Seekers. NUJS Law Review 41/6, 41-62.

Carrié, Shawn, Al Omar, Asmaa (2018). "'It's Against the Law': Syrian Refugees deported from Turkey Back to War." The Guardian, October 16, https://www.theguardian.com/global-development/2018/oct/16/syrian-refugees-deported-from-turkey-back-to-war (16. 10. 2018).

Dinçer, Osman Bahadir, Federici, Vittoria, Ferris, Elizabeth, Karaca, Sema, Kirişci, Kemal, Özmenek Çarmıklı, Elif (2013). Turkey and Syrian Refugees: The Limits of Hospitality. Washington D.C.: Brookings Institution, https://www.brookings.edu/ wp-content/uploads/2016/06/Turkey-and-Syrian-Refugees_The-Limits-of-Hospitality-2014.pdf (16. 10. 2018).

DRC (Danish Refugee Council) (2016). Closing Borders, Shifting Routes: Summary of Regional Migration Trends - Middle East, https://reliefweb.int/sites/reliefweb.int/files/ resources/DRC\%20-\%20ME\%20Migration\%20Trends\%20May.pdf (25. 5. 2018).

ECCHR (European Center for Constitutional and Human Rights) (2018). Term: Pushback, https://www.ecchr.eu/en/glossary/push-back/ (15. 10. 2018).

Edwards, Alice (2005). Human Rights, Refugees, and The Right 'To Enjoy' Asylum. International Journal of Refugee Law 17/2, 293-330. 
Farmer, Alice (2008). Non-Refoulement and Jus Cogens: Limiting Anti-Terror Measures That Threaten Refugee Protection. Georgetown Immigration Law Journal 23/1, 1-38.

Feller, Erika (2006). Asylum, Migration and Refugee Protection: Realities, Myths and the Promise of Things to Come. International Journal of Refugee Law 18/3-4, 509-536.

Fitzpatrick, Joan, Bonoan, Rafael (2003). Cessation of Refugee Protection. Refugee Protection in International Law: UNHCR's Global Consultations on International Protection (eds. Erika Feller, Volker Türk, Frances Nicholson). Cambridge: Cambridge University Press, 491-544.

GDP (Global Detention Project) (2015). Immigration Detention in Jordan, http://www. refworld.org/docid/556738404.html (25. 5. 2018).

Grahl Madsen, Atle (1966). The Status of Refugees in International Law. Leiden: AW Sijthoff. Grahl Madsen, Atle (1997). Commentary of the Refugee Convention 1951. Geneva: UNHCR, http://www.refworld.org/docid/4785ee9d2.html (25. 5. 2018)

Hathaway, James C. (2005). The Rights of Refugees Under International Law. Cambridge: Cambridge University Press.

HRF (Human Rights First) (2014). Lebanon Imposes Restrictions on Syrian Refugees, http://www.humanrightsfirst.org/blog/lebanon-imposes-restrictions-syrian-refugees (25. 5. 2018).

HRW (Human Rights Watch) (2013a). Jordan: Obama Should Press King on Asylum Seeker Pushbacks, https://www.hrw.org/news/2013/03/21/jordan-obama-should-pressking-asylum-seeker-pushbacks (25. 5. 2018).

HRW (Human Rights Watch) (2013b). Iraq/Jordan/Turkey:Syrians Blocked from Fleeing War, https://www.hrw.org/news/2013/07/01/iraq/jordan/turkey-syrians-blocked-fleeing-war (24. 5. 2018).

HRW (Human Rights Watch) (2014). Not Welcome: Jordan's Treatment of Palestinians Escaping Syria, https://www.hrw.org/sites/default/files/reports/jordan0814_ForUPload_0.pdf (24. 5. 2018).

HRW (Human Rights Watch) (2015). Turkey: Syrians Pushed Back at the Border, https:// www.hrw.org/news/2015/11/23/turkey-syrians-pushed-back-border (24. 5. 2018). HRW (Human Rights Watch) (2016a). Turkey: Border Guards Kill and Injure Asylum Seekers, https://www.hrw.org/news/2016/05/10/turkey-border-guards-kill-and-injureasylum-seekers (25. 5. 2018).

HRW (Human Rights Watch) (2016b). Jordan: 70,000 Syrians Trapped at Border, https:// www.hrw.org/news/2016/07/01/jordan-70000-syrians-trapped-border (25. 5. 2018). HRW (Human Rights Watch) (2016c). "I Just Wanted to be Treated Like a Person": How Lebanon's Residency Rules Facilitate Abuse of Syrian Refugees, https://www.hrw. org/sites/default/files/report_pdf/lebanon0116web.pdf (25. 5. 2018).

HRW (Human Rights Watch) (2017). Lebanon: New Refugee Policy a Step Forward, https://www.hrw.org/news/2017/02/14/lebanon-new-refugee-policy-step-forward (25. 5. 2018). 
ICL (Inter-agency Coordination Lebanon) (2015). Protection Monthly Dashboard April 2015, Beirut, http://reliefweb.int/sites/reliefweb.int/files/resources/April2015-ProtectionSectoralDashboard.pdf (25. 5. 2018).

IMBR (International Migrants Bill of Rights, with Commentary) (2013). Georgetown Immigration Law Journal 28/23, 23-103.

IRC (International Rescue Committee) (2016). Vulnerability Assessment of Syrian Refugee Men in Lebanon, https://www.rescue.org/sites/default/files/document/464/ irclebanonrefugeemensvulnerabilityassessment.pdf (25. 5. 2018).

Janmyr, Maja (2016). Precarity in Exile: The Legal Status of Syrian Refugees in Lebanon. Refugee Survey Quarterly 35, 58-78.

Kneebone, Susan (2006). The Pacific Plan: The Provision of 'Effective Protection'? International Journal of Refugee Law 18/3-4, 696-721.

Koca, Burcu Togral (2015). Deconstructing Turkey's "Open Door" Policy Towards Refugees from Syria. Migration Letters 12/3, 209-225.

Kogovšek Šalamon, Neža (2017). Mass Migration, Crimmigration and Defiance. Southeastern Europe 41/3, 251-275.

Lauterpacht, Sir Elihu, Bethlehem, Daniel (2001). The Scope and Content of the Principle of Non-Refoulement: Opinion, http://www.unhcr.org/protect/PROTECTION/3b33574d1.pdf (25. 5. 2018).

Law Regulating the Entry and Exit of Foreigners in Lebanon and their Exit from the Country. (1962), https://www.ilo.org/dyn/natlex/docs/SERIAL/39234/97115/ F1369890137/LBN-39234.pdf (25. 5. 2018).

Law No. 24 of 1973 on Residence and Foreigners' Affairs (1973), http://www.refworld. org/docid/556738404.html (28. 5. 2018).

Legomsky, Stephen A. (2003). Secondary Refugee Movements and the Return of Asylum Seekers to Third Countries: The Meaning of Effective Protection, http://www. refworld.org/docid/3f4de85d4.html (28. 5. 2018).

LHIF (Lebanon Humanitarian INGO Forum) (2014). Background Paper on Unregistered Syrian Refugees in Lebanon, http://hif.org/uploaded/News/d92fe3a1b1dd46f2a281254fa551bd09LHIF\%20Background\%20Paper\%20on\%20Unregistered\%20 Syrian\%20Refugees\%20(FINAL).pdf (25. 5. 2018).

Nessel, Lori A. (2015). Deliberate Destitution as Deterrent: Withholding the Right to Work and Undermining Asylum Protection. San Diego Law Review 52/2, 313-356.

NRC (Norwegian Refugee Council) (2014). The Consequences of Limited Legal Status for Syrian Refugees in Lebanon. Part Two: North, Bekaa, and South, https://www.nrc. no/globalassets/pdf/reports/the-consequences-of-limited-legal-status-for-syrian-refugees-in-lebanon.pdf.

NRC (Norwegian Refugee Council), IRC (International Rescue Committee) (2015). Legal status of refugees from Syria: Challenges and consequences of maintaining legal stay in Beirut and Mount Lebanon, http://www.refworld.org/docid/56cabc8c4. html (25. 5. 2018). 
Oxfam (2015). Lebanon: Looking Ahead in Times of Crisis, https://www.oxfam.org/ sites/www.oxfam.org/files/file_attachments/dp-lebanon-looking-ahead-timecrisis-141215-en_0.pdf (25. 5. 2018).

Oxfam (2017). A dangerous 'game': The Pushback of Migrants, Including Refugees, at Europe's Borders, https://www.oxfam.org/sites/www.oxfam.org/files/file_attachments/bp-dangerous-game-pushback-migrants-refugees-060417-en_0.pdf (28. 8. 2018).

Ramsden, Michael, Marsh, Luke (2014). Refugees in Hong Kong: Developing the Legal Framework for Socio-Economic Rights Protection. Human Rights Law Review $14 / 2,267-299$.

Rifai, Ryan (2015). "Turkey Denies Border Guards Shot Syrian Civilians." Al Jazeera, August 15, https://www.aljazeera.com/news/2015/08/turkey-border-guards-accused-shooting-syrians-150814183613359.html (16. 10. 2018).

Schneebaum, Steven M. (2010). The United Nations Must Work to Prevent the Illegal Constructive Refoulement of the People of Ashraf, https:/www.usccar.org/2011/10/ the-united-nations-must-work-to-prevent-the-illegal-constructive-refoulement-of-the-people-of-ashraf/ (25. 5. 2018).

UN General Assembly (1948). Universal Declaration of Human Rights (217 [III] A), http:// www.ohchr.org/EN/UDHR/Documents/UDHR_Translations/eng.pdf (28. 5. 2018).

UN General Assembly (1951). Convention Relating to the Status of Refugees, July 28, http://www.refworld.org/docid/3be01b964.html (25. 5. 2018).

UNHCR (UN High Commissioner for Refugees) (1977). Conclusion No. 6 (XXVIII) Non-Refoulement, http://www.refworld.org/docid/3ae68c43ac.html (24. 5. 2018).

UNHCR (UN High Commissioner for Refugees) (1980). Conclusion No. 17 (XXXI) Problems of Extradition Affecting Refugees, http://www.refworld.org/pdfid/4b28bf1f2. pdf (24. 5. 2018).

UNHCR (UN High Commissioner for Refugees), OAU (Organization of African Unity) (1980). Guidelines for National Refugee Legislation, with Commentary, http://www. refworld.org/docid/3ae6b32610.html (24. 5. 2018).

UNHCR (UN High Commissioner for Refugees) (1981). Conclusion No. 22 (XXXII) Protection of Asylum-Seekers in Situations of Large-Scale Influx, http://www.unhcr.org/excom/exconc/3ae68c6e10/protection-asylum-seekers-situations-large-scale-influx.html (24. 5. 2018).

UNHCR (UN High Commissioner for Refugees) (2016). The Situation of Palestinian Refugees in Lebanon, http://www.refworld.org/pdfid/56cc95484.pdf (24. 5. 2018).

UNHCR (UN High Commissioner for Refugees) (2017a). Syrian Regional Refugee Response: Inter-agency Information Sharing Portal, http://data.unhcr. org/syrianrefugees/regional.php\#_ga=2.176758885.174971918.14973458711547455566.1481142236 (24. 5. 2018).

UNHCR (UN High Commissioner for Refugees) (2017b). Return and Readmission of Palestinian Refugees from Syria (PRS) to Lebanon and Jordan, http://www.refworld. org/pdfid/5ab8cf9d4.pdf (24. 5. 2018). 


\section{POVZETEK}

\section{ZAVRNJENI SIRCI: KRŠITVE NAČELA NEVRAČANJA VTURČIJI, LIBANONU IN JORDANIJI Vasja BADALIČ}

Pravica iskati in uživati pribežališče pred preganjanjem je temeljna človekova pravica. Čeprav so Turčija, Jordanija in Libanon skupno sprejeli približno pet milijonov sirskih beguncev, številni protibegunski ukrepi, ki so jih uvedle vse tri države, nakazujejo, da mnogi sirski državljani niso imeli možnosti uveljaviti pravice do iskanja in uživanja pribežališča pred preganjanjem. Protibegunske ukrepe, ki so jih uporabile države gostiteljice, lahko razdelimo $v$ dve kategoriji.

Prva kategorija je vsebovala nezakonite ukrepe, s katerimi so vse tri države gostiteljice kršile načelo nevračanja. Ti ukrepi so merili predvsem na to, da sirskim državljanom preprečijo prečkanje meje in vložitev prošnje za azil. Prvi ukrep, ki so ga uporabile vse tri države gostiteljice, je bila zapora meje in preprečevanje prehoda sirskim državljanom, ki so bežali pred vojno. Drugi ukrep je bil uporaba selektivnih kriterijev za določanje skupin Sircev, ki jim ni bil dovoljen prehod meje (npr. palestinski in iraški begunci, ki so živeli v Siriji; mladi, neporočeni moški; sirski državljani brez veljavnih dokumentov; sirski državljani, ki so prihajali z območij, oddaljenih od libanonsko-sirske meje, ali z območij, za katere so libanonske oblasti trdile, da so varne). Tretji ukrep, ki sta ga uporabili Turčija in Jordanija, je bil samovoljno zapiranje in deportiranje sirskih iskalcev azila in beguncev.

Druga kategorija protibegunskih ukrepov je vsebovala ukrepe, s katerimi je ena med državami gostiteljicami - Libanon - ustvarila pogoje za posredno prisilno vračanje tako sirskih iskalcev azila kot tudi že registriranih sirskih beguncev, ki so že bili v Libanonu. Prvi ukrep je bil zaprtje pisarne UNHCR v Libanonu, edine institucije, ki je bila pristojna za obravnavanje prošenj za azil. Drugi ukrep je bil odvzem statusa nekaterim sirskim beguncem (npr. beguncem, ki so se začasno vrnili v Sirijo; beguncem, ki so bili registrirani po zaprtju meje na začetku leta 2015). Tretji ukrep je meril na to, da sirskim beguncem prepreči pridobitev dovoljenja za bivanje (npr. z uvedbo visokih pristojbin, ki jih begunci niso mogli plačati; s prenehanjem izdajanja dovoljenj za bivanje palestinskim beguncem). 